\title{
PERANAN TEKNOLOGI INFORMASI DALAM MENINGKATKAN KUALITAS PENDIDIKAN
}

\author{
Oleh \\ Kadek Surya Mahedy \\ Jurusan Manajemen Informatika, FTK, Undiksha
}

\begin{abstract}
ABSTRAK
Penerapan Teknologi Informasi (TI) saat ini telah menyebar hampir di semua bidang tidak terkecuali di sekolah ataupun perguruan tinggi. Sekolah sebagai institusi yang bertugas mengelola proses belajar mengajar, baik berupa pembelajaran langsung ataupun tidak lagsung. Kebutuhan akan TI sangat berhubungan dengan peran dari seorang guru untuk menguasi Teknologi Informasi sebagai mediator proses belajar mengajar.

Pada artikel ini akan dijelaskan peranan TI untuk meningkatkan kualitas pendidikan, baik dengan menggunakan media pembelajaran yang berbasis multimedia komputer ataupun dengan menggunakan media website atau yang sering dikenal dengan istilah cyber school. Pada artikel ini juga akan dijelaskan bagaimana kita memlih media pembelajaran yang tepat untuk proses pembelajaran.
\end{abstract}

\begin{abstract}
Application of Information Technology (IT) has now spread almost in all areas not least in the school or college. School as an institution in charge of managing the teaching-learning process, learning either directly or indirectly lagsung. The need for IT is related to the role of a teacher to menguasi Information Technology as a mediator of teaching and learning process.

This article will explain the role of IT to improve the quality of education, either by using the media multimedia-based learning using a computer or website or media is often known as the cyber school. In this article will also explain how we memlih appropriate learning media for the learning process.
\end{abstract}




\section{PENDAHULUAN}

\section{Latar Belakang}

Peran TIK (Teknologi Informasi dan Komunikasi) semakin nyata dalam berbagai bidang, bahkan dalam peningkatan keilmuan, penggunaan TIK diharapkan mampu mendorong kebangkitan Indonesia dalam era globalisasi. Untuk itu, pemerintah melalui Inpres no. 6/2001 telah berupaya untuk menetapkan kebijakan nasional dalam hal TIK dengan visi untuk membangun suatu pengetahuan yang berdasarkan masyarakat Telematika Nusantara. Karena sangat minimnya penggunaan / penerapan TIK di negara kita, menyebabkan semakin tertinggalnya negara kita dari negara lain. Menguasai TIK secara mendasar dapat mengurangi ketergantungan pada bangsa-bangsa lain.

Sebagai bahan pertimbangan, kita bisa melihat negara-negara tetangga kita seperti: Singapore, Malaysia atau India. Khususnya India, apakah mereka memiliki perekonomian yang lebih baik dari Indonesia? Kenapa mereka memiliki pakar-pakar IT yang sangat diperhitungan di dunia? Apakah SDM kita tidak bagus? Apakah guru-guru/tenaga pengajar yang melahirkan SDM tidak berkualitas? Untuk menjawab pertanyaan-pertanyaan di atas, baik secara pribadi maupun bersama-sama dengan pemerintah harus bisa intropeksi diri.

Mulai dari diri sendiri, seorang guru harus berusaha mulai mengenalkan TI (Teknologi Informasi) terhadap anak didiknya, atau menggunakan TIK tesebut dalam proses belajar mengajar. Proses inilah yang disebut sebagai Pembelajaran Berbasis Komputer.

Dengan dikeluarkannya kurikulum 2004, yang mengikutkan mata pelajaran TIK dalam pendidikan SMP, SMU dan SMK, adalah merupakan langkah yang sangat tepat untuk menghadapi era globalisasi ini. Lahirnya kurikulum TI 2004 ini, memunculkan masalah baru, bagaimana kita menerapkan/ mengimplementasikan Kurikulum TI 2004 ini, sehingga dapat mencapai sasaran dan tujuan yang diharapkan oleh pemerintah. Realita di lapangan, ada beberapa hambatan dalam 
penerapan kurikulum TIK ini. Baik itu, karena minimnya sarana (komputer) dan juga pengajar yang kompeten untuk memegang mata pelajaran tersebut.

Adapun rumusan masalah dalam artikel ini adalah bagaimanakah peranan Teknologi Informasi dalam meningkatkan kualitas pendidikan?

Tujuan dari penulisan artikel ini adalah untuk mengetahui peranan Teknologi Informasi dalam meningkatkan kualitas pendidikan. Artikel ini diharapkan mampu memeberikan pengetahuan TIK sehingga dapat meningkatkan kualitas pendidikan.

\section{MATERI DAN METODE}

Materi yang diangkat dalam artikel ini adalah mengenai peranan Teknologi Informasi dalam meningkatkan kualitas pendidikan. Materi ini diperoleh dengan cara pengumpulan dari berbagai informasi tentang TIK yang ada di internet pada beberapa website dan buku teks.

\section{PEMBAHASAN}

\subsection{Guru Dan Media Pembelajaran}

Dahulu ada anggapan bahwa guru adalah orang yang paling tahu. Kemudian paradigma ini berkembang menjadi guru lebih dahulu tahu. Namun sekarang bukan saja pengetahuan guru bisa sama dengan murid, bahkan murid bisa lebih dulu tahu dari gurunya. Itu semua dapat terjadi akibat perkembangan media informasi di sekitar kita. Pada saat ini, guru bukan satu-satunya sumber belajar. Banyak contoh, dimana siswa dapat lebih dahulu mengakses informasi dari media massa seperti surat kabar, televisi bahkan internet. Bagaimana guru menyikapi perkembangan ini? Ada tiga kelompok guru yang menyikapi hal ini:

(1) Kelompok yang tidak peduli, Seorang guru yang mempunyai rasa percaya diri yang berlebihan (over confidence). Hal ini, mungkin mereka berpegang kepada anggapan bahwa sampai kapanpun posisi guru tidak akan tergantikan. Dalam setiap proses pembelajaran 
tetap diperlukan sentuhan manusiawi. Teknologi tidak bisa menggantikan manusia. Bagaimanapun teknologi berkembang, guru adalah guru, harus digugu dan ditiru. Benar bahwa media tidak dapat menggantikan guru, namun sikap tidak peduli terhadap perkembangan, bukanlah sikap yang tepat. Walau bagaimana, lingkungan kita terus berkembang, tuntutan masyarakat terhadap kualitas guru semakin meningkat. Kita tidak bisa tak peduli.

(2) Kelompok yang menunggu petunjuk. Kelompok inilah yang paling banyak ditemukan. Mungkin ini akibat dari kebijakan yang selama ini, dimana guru dalam sistem pendidikan nasional hanya dianggap sebagai "tukang" melaksanakan kurikulum yang demikian rinci dan kaku. Kurikulum yang sangat lengkap dengan berbagai petunjuk pelaksanaannya, sehingga guru tinggal melaksanakan, tanpa boleh menyimpang dari pedoman baku.

(3) Kelompok yang mampu menyesuaikan diri. Sejalan dengan perubahan kurikulum dan otonomi pendidikan, bukan lagi masanya bagi guru untuk selalu menunggu petunjuk. Guru adalah tenaga profesional, bukan tukang. Oleh karena itu, sikap yang tepat untuk kita adalah cepat menyesuaikan diri. Guru perlu segera mereposisi perannya. Pada saat ini guru tidak lagi harus menjadi orang yang paling tahu di kelas. Namun ia harus mampu menjadi fasilitator belajar. Ada banyak sumber belajar yang tersedia di lingkungan kita, yang dapat dirancang untuk terlibat dalam proses pembelajaran. Guru yang baik akan merasa senang kalau muridnya lebih pandai dari dirinya.

\subsection{Perlunya Sebuah Media}

Pernakah anda menghadapi kesulitan dalam menjelaskan suatu materi pelajaran kepada murid anda? Misalnya anda akan menjelaskan tentang proses penyubliman, penguapan, pembekuan pada anak SMP, atau anda ingin menjelaskan pembentukan sebuah kubus dari jaring- 
jaring kubus. Mungkin kita bisa ambil contoh yang paling ektrim, anda ingin mendeskripsikan kereta api pada anak-anak SD yang terletak di daerah terpecil. Mungkin sebagian besar dari mereka tidak memiliki gambaran tentang sebuah kereta api, kecuali mereka pernah melihat gambarnya di TV, surat kabar atau media massa lainnya.

Dari beberapa contoh di atas, anda ingin menjelaskan sebuah kereta api (kita ambil contoh yang paling ekstrem). Ada beberapa cara yang mungkin anda lakukan:

(1) Anda akan bercerita tentang proses penyubliman, kereta api, jaring-jaring kubus. Anda bisa cerita mungkin karena pengalaman membaca buku, cerita orang lain atau pernah melihat gambar. Apabila murid anda tersebut sama sekali belum tahu, belum pernah melihat dari televisi atau gambar di buku misalnya, maka betapa sulitnya anda menjelaskan dengan kata-kata tentang objek tersebut. Kalau anda seorang yang ahli bercerita, tentu cerita anda akan sangat menarik bagi murid-murid. Namun tidak semua orang diberikan karunia kepandaian bercerita. Penjelasan dengan kata-kata mungkin akan menghabiskan waktu yang lama, pemahaman murid juga berbeda sesuai dengan pengetahuan mereka sebelumnya, bahkan bukan tidak mungkin akan menimbulkan kesalahan persepsi.

(2) Membawa murid studi wisata melihat objek itu. Cara ini merupakan yang paling efektif dibandingkan dengan cara lainnya. Namun berapa biaya yang harus ditanggung dan berapa lama waktu diperlukan? Cara ini walaupun efektif tapi tidak efisien. Tidak mungkin untuk belajar semua orang harus mengalami segala sesuatu.

(3) Anda membawa gambar, foto, film, video tentang objek tersebut. Cara ini akan sangat membantu anda dalam 
memberikan penjelasan. Selain menghemat kata-kata, menghemat waktu, penjelasan adapun akan lebih mudah dimengerti oleh murid, menarik, membangkitkan motivasi belajar, menghilangkan kesalahan pemahaman, serta informasi yang anda sampaikan menjadi konsisten.

Ketiga cara di atas dapat kita sebutkan, cara pertama sebagai informasi verbal, cara kedua berupa pengalaman nyata, sedangkan cara ketiga informasi melalui media. Diantara ketiga cara tersebut, cara ketiga adalah cara yang paling bijaksana dilakukan. Media kita perlukan agar pembelajaran lebih efektif dan efisien.

Masalahnya, mengapa sampai saat ini masih ada guru yang enggan menggunakan media dalam mengajar? Berdasarkan survey yang dilakukan terhadap guru-guru, sekurang-kurangnya ada enam penyebab guru tidak menggunakan media, yaitu:

(1) Menggunakan media itu repot

(2) Media itu canggih dan mahal

(3) Tidak bisa menggunakan

(4) Media itu hiburan, sedangkan belajar itu serius

(5) Tidak tersedia di sekolah

(6) Kebiasaan menikmati bicara

\subsection{Pertimbangan Dalam Memilih Media Pembelajaran}

Ada sejumlah pertimbangan dalam memilih media pembelajaran yang tepat. Untuk lebih mudah mengingatnya, pertimbangan tersebut dapat kita rumuskan dalam satu kata ACTION, yaitu akronim dari: access, cost, technology, interactivity, organization, novelty.

(1) Access, kemudahan akses menjadi pertimbangan pertama dalam memilih media. Apakah media yang kita perlukan itu tersedia, mudah dan dapat dimanfaatkan oleh murid? Misalnya, kita ingin menggunakan internet, perlu dipertimbangkan terlebih dahulu 
apakah ada saluran untuk koneksi ke internet? Akses juga menyangkut aspek kebijakan, misalnya apakah murid diijinkan untuk menggunakannya? Komputer yang terhubung ke internet jangan hanya digunakan oleh kepala sekolah, tetapi juga guru dan yang paling penting untuk murid.

(2) Cost, biaya juga harus dipertimbangkan. Banyak jenis media yang dapat menjadi pilihan kita. Media canggih biasanya mahal. Namun mahalnya biaya itu harus kita hitung dengan aspek manfaatnya. Semakin banyak yang menggunakan, maka unit cost dari sebuah media akan semakin menurun.

(3) Technology, mungkin saja kita tertarik terhadap media tertentu. Tapi kita perlu perhatikan apakah teknologinya tersedia dan mudah menggunakannya? Katakanlah kita ingin menggunakan media audio visual di kelas. Perlu kita pertimbangkan, apakah ada listrik, voltase listrik cukup dan sesuai?

(4) Interaktivity, media yang baik adalah yang dapat memunculkan komunikasi dua arah atau interactivitas. Setiap kegiatan pembelajaran yang anda kembangkan tentu saja memerlukan media yang sesuai dengan tujuan pembelajaran tersebut.

(5) Organization, pertimbangan yang juga penting adalah dukungan organisasi. Misalnya, apakah pimpinan sekolah atau yayasan mendukung? Bagaimana pengorganisasiannya. Apakah di sekolah ini tersedia satu unit yang disebut pusat belajar?

(6) Novelty, kebaruan dari media yang anda pilih juga harus menjadi pertimbangan. Media yang lebih baru biasanya lebih baik dan lebih menarik bagi siswa.

\subsection{Peran Teknologi Informasi Dalam Pembelajaran}

Komputer, sebagai pendukung teknologi informasi sudah banyak dimanfaatkan dalam pembelajaran, sehingga dikenal dengan istilah pembelajaran bermedia komputer atau sering disebut pembelajaran 
berbasis teknologi komputer. Pembelajaran bermedia komputer adalah cara untuk memproduksi atau menyajikan materi pembelajaran dengan menggunakan sumberdaya dengan basis mikroprosesor. Tugas para ahli teknologi pendidikan dalam hal ini adalah mendesain pembelajaran agar dapat disajikan dengan menggunakan komputer. Kegiatan utama siswa sebagai pemakai dalam pembelajaran yang memanfaatkan teknologi dengan basis komputer adalah mengakses informasi dari sumber informasi, yaitu komputer.

Proses pembelajaran sebenarnya didominasi oleh kegiatan manajemen informasi. Ada tiga komponen utama dalam informasi, yaitu pemakai, akses dan informasi. Dalam proses pembelajaran sebagai pemakai adalah siswa, sebagai informasi adalah materi pembelajaran yang berasal dari buku, basis data komputer, basis pengetahuan atau sumber informasi lainnya. Sedangkan akses adalah transfer informasi dari sumber informasi kepada siswa. Pada teknologi dengan basis komputer dikaji bagaimana mendesain pembelajaran dengan memanfaatkan sumberdaya komputer, termasuk di dalamnya pengaturan pemakai, pengaturan informasi pembelajaran dan pengaturan akses. Manajemen informasi dan teknologi dengan basis komputer juga melibatkan manajemen sumberdaya.

Memperhatikan uraian di atas ditambah dengan pengamatan terhadap perkembangan teknologi, tentunya tidak berlebihan ungkapan yang menyatakan bahwa "perpaduan antara sistem informasi dengan manajemen akan berkembang dan mempengaruhi Teknologi Pembelajaran, dimana manajemen pengambilan keputusan akan makin tergantung kepada komputerisasi informasi.

Dalam komputerisasi sumber pembelajaran, penekanan lebih diberikan pada keunggulan design perangkat lunak (software) daripada kecanggihan-kecanggihan perangkat keras (hardware). Pengaturan penampilan informasi, keramahan antar muka (interface), dan kemudahan dalam mengakses informasi yang dirasakan oleh pemakai (user) lebih 
menentukan keberhasilan proses pembelajaran daripada kecanggihan perangkat keras yang dipilih. Bukan berarti bahwa perangkat keras yang canggih tidak perlu, melainkan harus disesuaikan dengan alokasi biaya, yang penting perangkat keras yang digunakan kompatibel dengan sistem perangkat lunak yang dikembangkan.

Taksonomi penggunaan komputer dalam bidang pendidikan yang paling banyak digunakan adalah yang diusulkan oleh Taylor (1980), yang mengklasifikasikan penggunaan komputer dalam bidang pendidikan menjadi tiga kelompok yaitu: (1) komputer sebagai tutor, (2) komputer sebagai tool, dan (3) komputer sebagai tutee. Komputer sebagai tutor dimaksudkan untuk menjelaskan peran komputer sebagai alat untuk menyajikan materi pembelajaran yang diprogram secara elektronik. Komputer sebagai tool menjelaskan fungsi komputer yang amat luas sebagai alat bantu atau dalam terminologi McLuhan disebut perpanjangan tangan manusia, agar pekerjaan menjadi lebih cepat dan lebih efisien, misalnya administrasi biaya pendidikan, administrasi nilai, administrasi perpustakaan, dan administrasi lainnya. Komputer sebagai tutee berarti komputer sebagai objek untuk dikontrol melalui pemrograman, agar mampu memecahkan masalah.

Teknologi dengan basis komputer adalah cara untuk memproduksi atau menyajikan materi dengan menggunakan sumber berbasis mikroprosesor. Apabila diperhatikan klasifikasi penggunaan komputer dalam pendidikan dari Taylor, maka teknologi dengan basis komputer termasuk dalam klasifikasi komputer sebagai tutor. Akan tetapi perkembangan aplikasi komputer dalam pendidikan menunjukkan bahwa teknologi dengan basis komputer sudah

menambahkan tool ke dalam paket aplikasinya. Sehingga perbedaan menggunakan komputer dalam pendidikan sebagai tutor dan penggunaan komputer dalam pendidikan sebagai tool menjadi semakin kabur. 


\subsection{Karakteristik Komputer sebagai Media Pembelajaran}

Ada beberapa karakteristik dari teknologi berbasis komputer, baik perangkat keras maupun perangkat lunak, yang membuat teknologi tersebut dipilih untuk memproduksi dan menyajikan materi pembelajaran. Karakteristik dimaksud adalah sebagai berikut:

(1) Ide abstrak bisa disajikan dalam model dengan menggunakan kata-kata, simbol, grafik dan animasi sehingga lebih mudah dipahami siswa.

(2) Perpaduan animasi teks dan gambar dengan berbagai animasi tampilan juga dapat menarik minat siswa. Bahkan penggunaan multimedia dan hypermedia yang mampu memadukan teks, grafik dan suara akan lebih menarik perhatian siswa.

(3) Dapat mengakomodasi perbedaan siswa secara individu, menurut kemampuan, latar belakang kehidupan, pengalaman atau hobi. Suatu hal yang amat sulit untuk dikerjakan oleh seorang guru sendiri di kelas.

(4) Dapat digunakan secara random sehingga lebih mendukung pelaksanaan control learner.

(5) Pembelajaran bisa dibuat berorientasi pada siswa dengan teknik interaktif tingkat tinggi. Dialog bisa dibuat lebih lengkap dengan memanfaatkan basis data informasi atau bahkan basis pengetahuan.

(6) Faktor-faktor personal guru, seperti sikap, emosi atau persepsi yang dapat mempengaruhi proses pembelajaran dieleminir secara maksimal. Komputer tidak pernah marah atau kesal, sehingga penampilannya konstan dan memandang siswa sama. Faktor subyektifitas juga bisa dihilangkan secara maksimal karena komputer tidak punya perasaan untuk mengenali siswa cantik, nakal, kaya dan 
sebagainya. Melainkan hanya bertindak sesuai dengan logika program.

(7) Konvensi sosial yang dapat menghambat perkembangan siswa dapat diminimalkan karena komunikasi antar siswa atau siswa dengan guru difasilitasi oleh komputer. Komunikasi bermedia komputer relatif dapat mengeleminir perbedaan ruang dan waktu.

Dibalik karakteristik yang menguntungkan, pembelajaran berbantuan komputer masih memiliki keterbatasan dibandingkan dengan pembelajaran yang dimiliki guru. Keterbatasan yang dimaksud, adalah:

(1) Komputer tidak mampu mengenali situasi siswa, apakah siswa sudah lelah, merasa kesal atau menemui kesulitan. Apabila ini dibiarkan akan menimbulkan frustasi.

(2) Di tingkat awal, selain sebagai pengajar, guru juga bertindak sebagai pendidik dengan melakukan komunikasi interpersonal dengan siswa. Kemampuan mendidik ini tidak dimiliki komputer, karena komputer tidak mampu melakukan komunikasi interpersonal dengan siswa.

\subsection{Paket Program Pembelajaran Berbantuan Komputer}

Proses penyusunan paket PBK setidaknya melibatkan tiga bidang keahlian, yaitu materi pembelajaran, desain pembelajaran (Teknologi Pendidikan), dan pemrograman komputer. Paket PBK pada mulanya disusun menjadi paket program utuh, dimana materi pembelajaran dan instruksi pembelajaran diintegrasikan dalam satu file program. Bentuk PBK seperti ini dinilai kurang baik karena sangat kaku. Dialog antara sistem dengan siswa terbatas. Apabila materi sudah dikuasai siswa atau materi pembelajaran ingin disesuaikan dengan keadaan siswa maka penggantian materi pembelajaran amat sulit, dan harus dikerjakan oleh programer. 
Sejalan dengan perkembangan teknologi komputer, khususnya teknik basis data, muncul ide untuk memanfaatkan basis data informasi dalam PBK. Pada desain jenis ini paket PBK menjadi lebih fleksibel karena materi dan instruksi pembelajaran disimpan secara terpisah. Dialog antara sistem dan siswa bisa dibuat lebih kaya dengan mengatur basis data. Penggantian materi pembelajaran juga menjadi lebih mudah karena hanya mengganti file basis data, sehingga tidak mesti dikerjakan oleh pemrogram. Rupanya inovasi di bidang PBK berkembang dengan cepat menyertai perkembangan teknologi komputer. Perkembangan konsep intelegensi buatan pada beberapa bidang telah memberi ilham para ahli teknologi pendidikan untuk mengadopsi konsep tersebut untuk mengembangkan paket PBK.

Proses penyusunan paket PBK umumnya melalui tiga fase, yaitu fase analisis, fase pengembangan dan fase evaluasi. Fase analisis adalah penyiapan desain pembelajaran, meliputi analisis pembelajaran, perumusan tujuan pembelajaran, penyusunan alat evaluasi dan pemilihan strategi pembelajaran yang tepat. Desain pembelajaran yang telah disusun kemudian diprogram menjadi prototip program dalam fase pengembangan. Protipe program kemudian dievaluasi dalam fase evaluasi untuk mengetahui apakah prototip program sudah memenuhi kriteria pembelajaran yang diinginkan. Apabila kriteria sudah terpenuhi maka prototip dikembangkan menjadi paket PBK, sedangkan apabila kriteria belum tercapai maka dilakukan revisi. Bila terjadi kesalahan semantik (logika), maka revisi dilakukan mulai dari fase analisis. Sedangkan bila terjadi kesalahan sintaks (kode), maka revisi hanya dilakukan pada fase pengembangan. Hasil revisi kemudian dievaluasi lagi, dan begitu seterusnya sampai menjadi PBK yang siap dipakai.

Bentuk pembelajaran yang bisa dikembangkan adalah model tutorial,drill, permainan dan simulasi. Tutorial merupakan bentuk pembelajaran yang paling lengkap, yang umumnya digunakan untuk mengajar materi baru. Kegiatan yang mesti tercakup dalam tutorial antara 
lain memotivasi siswa, mengenali materi prasyarat, menyampaikan tujuan, penyajian materi disertai tanya jawab dan remidi dan diakhiri dengan latihan. Sementara itu drill hanya meliputi kegiatan bertanya dan memberikan umpan balik, yang digunakan untuk meningkatkan retensi dan transfer. Simulasi berarti merepresentasikan keadaan nyata. Berdasarkan simulasi itu siswa diminta menyusun hipotesis tentang hubungan antara fakta dari kejadian yang diamati.

Interaksi pembelajaran dalam PBK terjadi antara sistem dengan siswa. Siswa memberikan respon dan sebaliknya sistem memberikan umpan balik. Fokus pengkajian dalam hal ini antara lain bisa diarahkan ke penyempurnaan umpan balik sehingga dialog antara sistem dengan siswa lebih bermakna. Apakah umpan balik langsung disertai reinforcement, atau reinforcement diberikan setelah umpan balik tertentu merupakan kajian utama bidang ini. Beberapa penelitian tentang umpan balik yang sudah dilakukan antara lain umpan balik berupa komentar pendorong dan umpan balik korektif.

Ciri utama dari PBK adalah menerapkan pendekatan pembelajaran individual. Fleksibelitas sistem pengaksesan informasi bisa dimanfaatkan untuk mengadaptasi pembelajaran agar bisa mengakomodasikan perbedaan siswa secara individual. Adaptasi bisa dilakukan menurut struktur materi, kemampuan siswa maupun karakteristik individu lainnya, seperti latar belakang keluarga, minat atau hobby. Adaptasi terhadap kemampuan siswa dimaksudkan agar PBK mampu menyajikan materi sesuai dengan tingkat kemampuan siswa yang dideteksi sebelumnya. Pada sisi lain, adaptasi terhadap latar belakang keluarga, minat atau hobby dimaksudkan agar PBK mampu menyajikan materi pembelajaran dalam konteks yang sesuai dengan latar belakang keluarga, minat atau hobby yang dideteksi sebelumnya. Pendekatan ini diharapkan mampu lebih memotivasi siswa untuk belajar karena apa yang dipelajari dirasakan sesuai dengan kebutuhan, kemampuannya dan pengalamannya. 
Komponen motivasi sangat penting dalam penyusunan PBK. Pengkajian di sini bisa difokuskan pada penyususnan PBK yang mampu membangkitkan dan memelihara motivasi siswa. Komponen motivasi yang umum digunakan dalam PBK adalah yang direkomendasikan oleh Keller yang disebut komponen ARCS. Menurut Keller ada empat komponen motivator dalam pembelajaran, yang disingkat ARCS, yaitu A(Attention), R(Relevance), C(Confidence) S(Satisfication). Attention dimaksud, siswa akan termotivasi untuk belajar jika materi pembelajaran sesuai dengan kepentingannya. Confidence berarti siswa akan termotivasi belajar jika merasa mampu untuk menguasai materi yang diajarkan. Satisfication berarti siswa akan termotivasi untuk belajar jika proses pembelajaran mampu memuaskan siswa. Komponen motivasi terkait erat dengan adaptasi materi terhadap individu siswa.

\section{PENUTUP}

\subsection{Simpulan}

Teknologi Informasi dapat dimanfaatkan untuk meningkatkan kualitas sumber daya manusia dan secara otomatis dapat berpengaruh pada peningkatan kualitas pendidikan itu sendiri. Hal ini disebabkan, karena teknologi informasi dapat dimanfaatkan sebagai alat bantu pembelajaran dalam berbagai bentuk, seperti basis data, sistem pakar atau multimedia/hipermedia. Di lain sisi, teknologi informasi juga dapat berperan dalam pembinaan sikap. Sikap yang bisa ditingkatkan meliputi sikap teliti, sikap konsisten dan sikap tepat waktu. Hal ini terjadi karena pembiasaan dalam bekerja dengan teknologi informasi yang menuntut kebenaran data, konsistensi data dan ketepatan waktu dalam penyampaian data. Peran yang tidak kalah pentingnya dari teknologi informasi dalam meningkatkan kualitas pendidikan adalah membina etika dan estetika. Etika lahir dari kebiasaan menghargai pendapat dan hasil karya orang 
lain, sementara estetika lahir dari kebiasaan menyajikan informasi dengan indah dan menarik hati.

Di sisi lain, peran teknologi informasi untuk meningkatkan kualitas pendidikan, tentunya terdapat pula pengaruh negatif dari teknologi informasi. Kemajuan teknologi informasi juga menghasilkan pembuat virus yang sewaktu-waktu dapat mengancam data. Selain itu, banyak hacker yang lahir dari kemajuan teknologi informasi, yang dapat merusak basis-data perusahaan atau institusi lainnya. Akan tetapi, itu semua harus diakui sebagai efek samping dari kemajuan teknologi, yang mesti diwaspadai tanpa harus takut menggunakan teknologi informasi. Dengan kata lain, virus atau hacker bukan dijadikan halangan untuk memajukan teknologi informasi, dengan asumsi bahwa pengaruh positifnya masih jauh lebih besar. Peran teknologi informasi untuk meningkatkan pengetahuan dan keterampilan, sikap dan etika serta estetika tetap harus diperjuangkan. Dengan demikian, tujuan pendidikan untuk mencerdaskan bangsa dengan beretika dan berestetika dapat terwujud.

\subsection{Saran}

Disarankan kepada guru dan siswa agar mampu memanfaatkan TI khususnya dalam bidang pendidikan, karena dengan menguasai TI akan dapat meningkatkan kualitas pendidikan, baik dari segi hasil belajar dan penguasaan teknologi informasi.

\section{DAFTAR PUSTAKA}

Ade Koesnandar, Guru dan Media Pembelajaran, Jurnal Teknodik No. 13, Jakarta, 2003 
I Made Candiasa, Peranan Teknologi Informasi untuk Meningkatkan Kualitas Sumber Daya Manusia, Singaraja, 2004

Lani Sidharta, Sistem Informasi Bisnis (Analisis dan Desain Sistem Informasi Bisnis), Elexmedia Komputindo, Jakarta, 1996

Sih Retno Hastuti, Media Pembelajaran dan Proses Belajar Mengajar,http://berita.penabur.org/200203/ media_pendidikan \& proses_kbm.htm Diakses tanggal 19 April 2005

Sukirno, PENDIDIKAN BERBASIS KOMPUTER, http://k03jkt. penabur.org/media komputer.htm Diakses tanggal 19 April 2005.

Yuliana dan Mariani, Teknologi Informasi dan Komunikasi dalam Peningkatan Mutu Pendidikan di Perguruan Tinggi, Jurnal Pendidikan dan Kebudayaan, Jakarta, 2004 